\title{
FREDRIC JAMESON \\ e os estudos culturais: resenha da textualidade do mundo
}

Isaías Francisco de Carvalho

Resenhar o texto "Sobre os 'estudos de cultura" é, na verdade, um gesto duplo. Uma resenha da resenha. Esse texto de Fredric Jameson (In: Novos Estudos CEBRAP, n. 39. Tradução de John Manuel Monteiro e Otacílio Nunes, p. 11-48, julho, 1994) é, citando o resumo proposto por seus tradutores para o português, uma resenha da coletânea Cultural Studies (GROSSBERG, Lawrence; CARY, Nelson; TREICHLER, Paula A.Orgs. Nova York: Routledge, 1992), que reproduz os 41 textos apresentados em uma conferência sobre o campo dos estudos culturais em Urbana-Champaign, no primeiro semestre de 1990. A ideia central desse texto introdutório é a de que, apesar de os Estudos de Cultura poderem ser considerados como um plano arquitetônico para uma disciplina acadêmica nova, Fredric Jameson prefere uma abordagem política e social, como um projeto para a constituiçâo de um "bloco histórico" nos termos gramscianos, ou seja, uma aliança entre diversos grupos sociais - um tipo de substituto do marxismo.

Desse modo, como resenha da resenha, o que se faz aqui é propor um levantamento dos temas e recortes privilegiados por Jameson, pois não se pretende repetir os nomes dos autores dos inúmeros textos mencionados, com raras exceçôes, a começar por Raymond Williams, considerado por Jameson um dos poucos ícones ainda em operação no novo movimento. O que interessa, portanto, são aqueles momentos em que Jameson, após citar vários autores e textos da coletânea, sintetiza o que está 
analisando, sendo esta uma resenha de suas visóes e propostas, afinal, sempre tendo em vista o eixo central do texto como delineado no resumo de seus tradutores, John Monteiro e Otacílio Nunes.

Interessa apontar como Jameson sugere que seu "comentário" sobre a conferência tem o formato de "um diagnóstico desse evento em particular e da 'ideia' de Estudos Culturais que ele encarna”, acrescentando que deve colocar as suas cartas na mesa, no melhor estilo do próprio campo - o estabelecimento relacional e contextual do lugar de fala. Essa postura implica que, para Jameson, não importa o formato final que o programa venha a ter, ou até se haverá alguma disciplina acadêmica dessa natureza em termos formais. O autor se confessa descrente na reformulação dos programas universitários, mas confiante de que, uma vez que aconteça, na seara pública, a forma mais apropriada de discussão ou argumentação, o objetivo dos Estudos de Cultura terá se realizado, não importando a estrutura departamental em que tal discussão seja feita. Desse modo, Jameson assume um posicionamento "processual”, ou seja, uma postura nãoteleológica, privilegiando a própria discussão do campo e as articulaçóes que vão sendo mantidas com outras áreas e disciplinas estabelecidas.

Dada essa "contextualização" inicial, decide-se pela pontuação sucinta das questôes mais cruciais do texto, sem seguir a divisão em partes que o próprio autor estabeleceu, abordando os seguintes temas: grupos, marxismo, o conceito de articulaçáo, cultura e libido, o papel dos intelectuais, populismo, geopolítica e utopia. Dentre esses tópicos, os principais tendem a ser "grupo" e "utopia”, enquanto os outros conceitos são levantados para subsidiar a argumentação. É assim que Jameson ilustra as relaçóes entre Estudos Culturais e algumas das disciplinas estabelecidas, tais como História e o Novo Historicismo, a antropologia, a sociologia e a comunicaçáo, sendo esta última a que mais parece estar apta a se articular com o campo da crítica cultural, pois os programas de Comunicaçóes são recentes o suficiente para estabelecer em muitos sentidos uma coincidência com o novo empreendimento culturalista. Quanto ao campo historiográfico, após estabelecer a limitação da interseção entre Estudos Culturais e História, bem como distinguir o trabalho individual do historiador com os arquivos do trabalho coletivo mais apropriado dos culturalistas, Jameson continua dizendo que o Novo Historicismo é competição básica e, seja qual for a perspectiva histórica, um elemento sintomático de natureza semelhante à dos Estudos Culturais na tentativa de criticar a nova textualidade do mundo, além de sua vocação para substituir discretamente, e de modo respeitável, o marxismo. É importante, para a compreensão geral do texto, sublinhar essa assertiva parentética, pois a dimensão utópica dos Estudos Culturais, esse "desejo chamado intelectual orgânico", é uma das questóes centrais do texto. 
Quanto à problemática da identidade de grupo, Jameson ressalta como a coletânea que resenha e, de modo geral, todo o campo dos Estudos Culturais não se prestam a expressóes de "identidades puras enquanto tais", sendo um espaço para representaçôes mais complexas e menos essencialistas de identidade de grupo. Em uma posição discordante com essa visão de abertura e inter-relação, Jameson aponta o texto do australiano Tony Bennett como "um genuíno 'pensamento do outro', rastreando e denunciando diligentemente os erros ideológicos de todos [os] inimigos dentro da esquerda na mais enfática tradição de patrulhamento althusseriano" (p. 25), sendo um começo "enganoso" para a leitura da coletânea, vez que se trata do texto de abertura do volume.

O conceito de articulação, por seu turno, é chave no cenário dos Estudos Culturais, e, portanto, na coletânea que Jameson resenha, pois se constitui o que de mais próximo de uma teoria (mesmo que não uma "grande teorização" ou "grande narrativa") pode ser apontado nesse campo, pois implica um tipo de estrutura rotativa, um processo de troca entre diversas entidades, na qual a ideologia de uma dessas estruturas permeia e se mescla com as demais. Como se vê, ainda é na dimensão do conceito de grupo que a discussão se dá, bem como a definição do termo "cultura", que é problematizada nesse sentido, "pois a cultura - a versão mais fraca e secular daquilo que se chama religião — não é em si uma 'substância' ou fenômeno, é uma miragem objetiva que surge do relacionamento entre pelo menos dois grupos." Ou ainda: "uma 'cultura' é o conjunto de estigmas que um grupo carrega aos olhos do outro grupo (e vice-versa)" (p. 29). De fato, o relacionamento entre diferentes culturas sempre pressupóe luta e violência, dentro das duas formas de relacionamento primordiais entre grupos: a inveja e a aversão.

Finalmente, grupos, tidos como “entidades imaginárias", são sempre conflitantes. Daí decorre que as várias políticas da diferença, embutidas nas práticas de "identidade de grupo", só tiveram origem viável nas identidades sociais geradas por uma sociedade de consumo, portanto no âmbito do econômico, principalmente. Além disso, essas consideraçôes podem nos guiar para as "fronteiras de todo um campo novo, que náo é mais nem antropologia nem sociologia no sentido tradicional, mas que certamente devolve à cultura seu significado interior oculto como espaço dos movimentos simbólicos de grupos em relação agonística uns com os outros" (p. 35).

Para concluir junto com Jameson, é importante assinalar a dimensão de utopia que perpassa o campo, mas que atinge diretamente o papel e a posição do intelectual, seja como "groupie", "fâ" ou "intelectual orgânico". O dilema que se impóe é o papel e a distância do intelectual diante do grande objeto que pode ser chamado de "realidade 
cultural", ou ainda o problema da representação, visto que é chegado "o momento em que nossa própria função e status social enquanto intelectuais retorna vigorosamente, já que é uma funçâo mediada pela geopolítica, e seu valor é conferido pelo próprio sistema mundial e pelo nosso posicionamento nele" (p. 47). Finalmente, em seu "comentário", Jameson oferece (e aprende) liçóes e reflexôes que apontam para a consolidaçấo — sem o sentido tradicional e institucional do termo - dos Estudos Culturais como uma metodologia de "leitura" da textualidade do mundo a partir de um posicionamento de pluralidade, de engajamento e de utopias que pairam "como uma espécie de firmamento estelar sobre essa coletânea, como na verdade sobre os Estudos de Cultura em geral" (p. 48). As duas últimas décadas mostraram que Jameson fazia previsões e descriçôes lúcidas nesse comentário sobre os estudos de cultura. Trata-se de um texto atual em sua importância como introdução aos Estudos Culturais.

\section{$\operatorname{son} 2$}

